Brit. J. industr. Med., 1964, 21, 1.

\title{
THE CONCEPT OF ACCIDENT PRONENESS: A REVIEW
}

\author{
BY \\ PETER FROGGATT and JAMES A. SMILEY \\ From the Department of Social and Preventive Medicine, The Queen's University, Belfast
}

(RECEIVED FOR PUBLICATION MAY 8, 1963)

The term accident proneness was coined by psychological research workers in 1926 . Since then its concept - that certain individuals are always more likely than others to sustain accidents, even though exposed to equal risk - has been questioned but seldom seriously challenged.

This article describes much of the work and theory on which this concept is based, details the difficulties encountered in obtaining valid information and the interpretative errors that can arise from the examination of imperfect data, and explains why accident proneness became so readily accepted as an explanation of the facts.

A recent hypothesis of accident causation, namely that a person's accident liability may vary from time to time, is outlined, and the respective abilities of this and of accident proneness to accord with data from the more reliable literature are examined.

The authors conclude that the hypothesis of individual variation in liability is more realistic and in better agreement with the data than is accident proneness.

\section{Introduction}

In England in 1840 about 10,000 deaths occurred by accidental violence; of these, nearly 800 were caused by 'coaches, carriages, wagons and carts' (Registrar-General, 1846), a crude death rate of 0.63 per thousand population. During the early eighteen-seventies the crude death rate from accidental violence attained a peak of about 0.72 per thousand population, and although this was due mainly 'to the great increase in the mechanical forces in action in the country and to a want of a corresponding increase in the means of protection against their destructive application' (Farr, 1865), deaths on the road were deemed of sufficient consequence to be specified by William Farr in his annual 'Letter' to the Registrar-General, 'where [in the streets of London] children, women, old people and even vigorous men are killed weekly by horses and carriages of various kinds' (Farr, 1865). By 1961 the crude death rate from accidental violence (other than suicide) had dropped to $0 \cdot 38$, and in addition the pattern of deaths had altered radically; road accidents then accounted for $35 \%$ of the total of accidental deaths compared to $8 \%$ in 1840 , while such deaths in workplaces, mines, and factories, once tragically so numerous, have fallen to less than $6 \%$ of the total (Chief Inspector of Mines, 1957; Chief Inspector of Factories, 1960). Also, over 300,000 persons are injured each year on the roads of Britain (Monthly Digest of Stastitics, 1960) and over 400,000 seriously enough in British factories, mines, and workplaces to be absent from work for more than three days (Chief Inspector of Mines, 1957; Chief Inspector of Factories, 1960); whilst hundreds of thousands of accidents occur each year to persons in all walks of life and for which there are no adequate records. The picture is one of tragic wastage of life and potential, of loss of production, and of an overwhelming addition to the burden of human suffering.

There is a basic unity in folklore. In the absence of a category of natural causes, primitive man considered injury and disease to be the dispensation of unplacated spirits or the effect of human malevolence manifested through some evil eye which could destroy him as surely as Wotan destroyed Hunding. Scientific objectivism, dominant in nineteenthcentury European thought, countenanced no polemics; accidents were accidents, the causative agent external and there for all to see. Industrial accidents, largely ignored by Agricola (1556) and Ramazzini (1705), were generally considered the inevitable price of mechanization and improved protection essential to their prevention: 'Scarcely one would occur, I believe, if proper care were taken to case the dangerous parts' (Thackrah, 1832). Not everyone agreed unreservedly: 'What are called accidental deaths are often the result of negligence, wilfulness or rashness' (Farr, 1865), and whether Farr had in 
mind the operator, designer or employer, or all three, may be inferred from the following passage: 'The introduction of every new force is followed by a certain number of deaths. The chances of death are increased. And the people about the machines or instruments, which the force animates, are untrained in their use, and so do not avoid fatal dangers that with the requisite precautions are not inevitable' (Farr, 1875). In industry, increased protection rapidly reduced the accident rate, but by the First World War this beneficence had clearly exposed the fallacies of considering only environmental factors: 'It is perhaps not generally recognised that machinery is responsible for only a minority of accidents. . . . The Home Office records show that more than twothirds of such accidents are due to other causes. . . It has been estimated that the percentage of avoidable accidents in some industries is as much as sixty per cent' (Safety Committees in Factory and Workshops, 1918) (our italics).

There were two main approaches towards elucidating these 'other causes'. The first was research into the physical environment and its effect on such factors as fatigue; this latter was considered a physico-chemical state of the body until Elton Mayo's investigations at the Hawthorne factory in Chicago during the nineteen-twenties first challenged its experimental basis (Roethlisberger and Dickson, 1939). The second approach followed logically from the work of Greenwood and Woods (1919) and Greenwood and Yule (1920), whose results 'indicate that varying individual susceptibility to "accident" is an extremely important factor in determining the [accident] distribution'. The consequences of this second approach form the subject of this review.

\section{The Statistical Background}

Apart from von Bortkiewicz's (1898) classic exercise on the distribution of deaths from horsekicks in 10 Prussian army corps over 20 years, Greenwood (Greenwood and Woods, 1919; Greenwood and Yule, 1920) was the first, so far as is known, to study certain laws of probability relating specifically to the numerical distribution of accidents, in his case accidents among groups of women munition workers during the First World War. In this he was stimulated by his experiences as a member of the Committee on the Wartime Flying Service (Greenwood, 1927) and by the conclusions of $H$. M. Vernon (1918) that, when working hours among women munition workers were reduced, the fall in the number of accidents they incurred was greater than would have been expected had there been a linear relation between hours of work and number of accidents sustained.
Greenwood considered three hypotheses.

1. That accidents were accidents in the strictest sense and their allocation to human beings at risk in an unchanging environment was analogous to the throwing of a six or the dealing of an ace, i.e. truly random. In this event the frequency distribution of accidents among individuals would conform to a type of 'pure chance' distribution similar to Poisson's (1837) approximation to the binomial (the 'Poisson distribution'). In practice the Poisson distribution failed to 'fit', i.e. did not graduate, the observed frequency distributions in the original series, and thus Greenwood modified the hypothesis of random distribution, as in (2) and (3) below.

2. That after incurring an accident an individual becomes ipso facto subsequently more or less likely to incur another, i.e. first accidents distributed at random, subsequent accidents on some other law of probability. Greenwood (Greenwood and Yule, 1920) was able to arrive at a general solution to this problem but in a form unsuitable for computation. However, by making the simplifying assumption that the probability changes after the first accident but not again, no matter how many accidents are subsequently incurred, a solution was reached which in fact was easy to apply. Greenwood called this theoretical distribution the 'Single-Biassed' (later termed the Burned-Fingers distribution by Arbous and Kerrich (1951)), but although it frequently fitted the observed accident frequency distributions, for various reasons he doubted its theoretical justification: 'Since ... . we do not believe that the theoretical basis for this scheme either in the modified [single-bias] or original form is appropriate to the class of problems with which we are dealing, the resultant expressions are at best mere smoothing formulae, and when their application involves a large amount of arithmetic do not have any value from that point of view' (Greenwood and Yule, 1920).

3. That there exists $a b$ initio differentiation among the population members, by which it is supposed that individuals do not start equal (as in (1) and (2) above) but that some are inherently more likely to incur accidents than others, i.e. that initial liability to accident is a variable and not a constant. On the purely practical basis that this accident liability would be a continuously distributed variable ranging from zero far into the positive direction and would be skew, i.e. would have a pronounced 'tail' at higher values of liability, Greenwood chose a particular skewed curve, known as the Pearson type III curve, to represent this theorized distribution. The selection of this curve from the range of appropriately skewed curves available was arbitrary and mainly for the technical reason that it was easy 
to handle in practice. This emphasis on technical facility rather than theoretical justification is one of the most important facts to appreciate about the statistical theory of accident causation. It has become obscured, but Greenwood (Greenwood and Yule, 1920; Greenwood, 1941, 1949, 1950) used unambiguous language; for example: 'The choice of the binomial [Pearson type III] curve to represent the distribution of the continuously varying liabilities throughout the "population" has been dictated by considerations of practical convenience. An infinity of skew curves fulfilling the required conditions might be imagined but no objective evidence favouring one more than another can be produced' (Greenwood and Yule, 1920) (our italics). In fact Newbold (1927), in her comprehensive study, did not consider Greenwood's choice of the Pearson type III curve necessarily a good one, only that it was mathematically reasonable.

The emergent distribution was termed by Greenwood, perhaps unfortunately, the Distribution of Unequal Liabilities, and in fact it successfully graduated the data from all the 14 groups of female munition workers in the original series (Greenwood and Woods, 1919). Examples of the goodness of fit of the three theoretical distributions considered to one of the original sets of data are given in Table 1.

TABLE 1

FREOUENCY DISTRIBUTION OF ACCIDENTS AMONGST 648 WOMEN MUNITION WORKERS OVER FIVE WEEKS, AND RESULTS FROM FITTING OF THREE THEORETICAL MODELS (ABRIDGED FROM GREENWOOD AND YULE, 1920)

\begin{tabular}{|c|c|c|c|c|}
\hline \multirow{2}{*}{$\begin{array}{l}\text { No. of } \\
\text { Accidents } \\
\text { Incurred }\end{array}$} & \multirow{2}{*}{$\begin{array}{c}\text { No. of } \\
\text { Women } \\
\text { Incurring } \\
\text { Accidents }\end{array}$} & \multicolumn{3}{|c|}{$\begin{array}{l}\text { Accident Frequency when } \\
\text { Distribution was }\end{array}$} \\
\hline & & $\begin{array}{c}\text { By Chance } \\
\text { (Poisson) }\end{array}$ & Single-biassed & $\begin{array}{c}\text { Unequai } \\
\text { Liabilities }\end{array}$ \\
\hline $\begin{array}{l}0 \\
1 \\
2 \\
3 \\
4 \\
5 \\
\end{array}$ & $\left.\begin{array}{r}448 \\
132 \\
42 \\
21 \\
3 \\
2\end{array}\right\} 26$ & $\left.\begin{array}{c}406 \\
189 \\
45 \\
7 \\
1 \\
0 \cdot 1\end{array}\right\} 8 \cdot 1$ & $\left.\begin{array}{r}452 \\
117 \\
56 \\
18 \\
4 \\
1\end{array}\right\} 23$ & $\left.\begin{array}{r}442 \\
140 \\
45 \\
14 \\
5 \\
2\end{array}\right\} 21$ \\
\hline Total & 648 & $648 \cdot 1$ & 648 & 648 \\
\hline \multicolumn{2}{|c|}{$x^{2}$} & $\begin{array}{r}61 \cdot 280 \\
\nu=2\end{array}$ & $\begin{array}{r}5.845 \\
\nu=2\end{array}$ & $\begin{array}{l}1.927 \\
\nu=1\end{array}$ \\
\hline \multicolumn{2}{|c|}{$\mathbf{P}$} & $P<0.001$ & $0.10>P>0.05$ & $0.20>P>0.10$ \\
\hline \multicolumn{2}{|c|}{ Significance } & Significant & $\begin{array}{l}\text { Not } \\
\text { significant }\end{array}$ & $\begin{array}{l}\text { Not } \\
\text { significant }\end{array}$ \\
\hline
\end{tabular}

When considering this evidence three warnings are necessary. First, there is a widely held belief that, if in any period a minority of the individuals at (equal) risk incurred a majority of the total accidents sustained, then the accidents could not have been distributed at random, i.e. could not have been due to chance alone: 'It has been recognised for many years that some drivers have more mishaps on the road than could be accounted for by chance alone; and up-to-date insurance records suggest that less than 20 per cent of certain groups of drivers report over half the accidents. . . . growing interest in this odd distribution ... (Lancet, 1961) (our italics). But such a distribution is not 'odd'. In Tables 2 and 3 the numbers of individuals expected to incur $0,1,2 \ldots$ accidents, if the accidents were distributed entirely at random, are calculated for two examples in which the mean number of accidents per individual is respectively greater and less than 1 . In the first example, $40 \%$ of the in-

TABLE 2

THEORETICAL DISTRIBUTION OF 1470 ACCIDENTS OVER 1060 INDIVIDUALS (CALCULATED FROM POISSON'S LIMIT)

\begin{tabular}{|c|c|c|}
\hline $\begin{array}{l}\text { No. of } \\
\text { Accidents }\end{array}$ & $\begin{array}{c}\text { No. of } \\
\text { Individuals }\end{array}$ & $\begin{array}{c}\text { Total No. of } \\
\text { Accidents Incurred }\end{array}$ \\
\hline $\begin{array}{r}0 \\
1 \\
2 \\
3 \\
4 \\
5 \\
\geqslant 6\end{array}$ & $\left.\begin{array}{r}266 \\
368 \\
256 \\
119 \\
42 \\
6 \\
3\end{array}\right\} 40 \%$ & $\left.\begin{array}{r}0 \\
368 \\
512 \\
357 \\
168 \\
30 \\
35\end{array}\right\} 75 \%$ \\
\hline Total & 1060 & 1470 \\
\hline
\end{tabular}

Mean $=1.39$

TABLE 3

THEORETICAL DISTRIBUTION OF 301 ACCIDENTS OVER 500 INDIVIDUALS (CALCULATED FROM POISSON'S LIMIT)

\begin{tabular}{|c|c|c|}
\hline $\begin{array}{l}\text { No. of } \\
\text { Accidents }\end{array}$ & $\begin{array}{c}\text { No. of } \\
\text { Individuals }\end{array}$ & $\begin{array}{c}\text { Total No. of } \\
\text { Accidents Incurred }\end{array}$ \\
\hline $\begin{array}{r}0 \\
1 \\
2 \\
3 \\
\geqslant 4\end{array}$ & $\left.\begin{array}{r}274 \\
165 \\
49 \\
10 \\
2\end{array}\right\} 12 \%$ & $\left.\begin{array}{r}0 \\
165 \\
98 \\
30 \\
8\end{array}\right\} 45 \%$ \\
\hline Total & 500 & 301 \\
\hline
\end{tabular}

dividuals incurred $75 \%$ of the accidents; in the second, $12 \%$ incurred $45 \%$ of the accidents. In fact, the smaller the mean number of accidents-and in accident studies it is usually very small-the greater will this apparent distortion be.

Secondly, if a theoretical distribution fits an observed distribution, e.g. as does the Distribution of Unequal Liabilities to most accident frequency distributions, this does not mean that the hypothesis on which the distribution was based-in this case inherent unequal initial liability to accident-is necessarily the correct one in the circumstances. At logic there is an infinite number of hypotheses, any or all of which may give rise to theoretical distributions which graduate the data with equal success. This is why one should not reason from observed events to the probabilities of the hypotheses which 
may explain them. Consequently the hypothesis associated with the Distribution of Unequal Liabilities cannot on this evidence alone be accepted as an explanation of the facts. Other evidence is required. Thirdly, the Distribution of Unequal Liabilities itself can arise on hypotheses other than that of unequal initial liability. When evolving his hypotheses Greenwood had to assume equal risk to accident and an unchanging environment among his group members, but if in fact some individuals in an experimental population were more (or less) exposed to risk than their colleagues, or if the environment changed in an unequal fashion for the group members over the period of study, then the Distribution of Unequal Liabilities could arise when in fact accidents were randomly distributed among the subgroups of true equal-risk exposure. Again, suppose all persons in an equal-risk group were initially equally likely to incur an accident. Then, if the probability of sustaining an accident changes after an accident has been incurred, the Distribution of Unequal Liabilities may again arise if the law of change for the probability is suitably chosen (Kermack and McKendrick, 1925; Irwin, 1941; Arbous and Kerrich, 1951). And there are other alternative hypotheses which produce the same distribution, some being coherent in the accident situation (e.g. Lüders, 1934; Irwin, 1941) and some, derived for other purposes, absurd (e.g. Thyrion, 1960). In fact, a successful fit to accident frequency distributions with the Distribution of Unequal Liabilities does not necessarily require one to assume unequal initial liability to accident, due to factors in propria persona, at all. This is fundamental but has seldom been emphasized in the medical literature and even less frequently understood. However, before one considers the propriety of any hypothesis of accident causation the adequacy of the data employed must be examined.

\section{Accident Data}

Arbous and Kerrich (1951) defined an accident: 'In a chain of events, each of which is planned or controlled, there occurs an unplanned event which, being the result of some non-adjustive act on the part of the individual (variously caused) may or may not result in injury'. This contains the essentials of most acceptable definitions. It is clear that what one normally considers to be an accident is in fact the outcome of an accident, and also that 'near misses', included by the definition, are not so considered. As a result most investigators take an 'accident' to mean material damage or personal injury. If chance alone decides the outcome of an unplanned event, interpretative errors arising from these deficiencies will not be important, but this supposition may be incorrect (Cresswell and Froggatt, 1963). However, more serious errors arise from using data inadequate for one or more of the following reasons.

Inequality of Risk.-It is virtually impossible to obtain a group in which every member is exposed to an exactly similar risk of incurring an accident. In industry, the first source tapped for accident data, persons in the same trade and/or working in the same shop are usually assumed to be at equal risk, but in fact they rarely are. To try to overcome this difficulty, Whitfield (1954) adopted (for colliery workers) an 'accident coefficient' based on the product of the time worked on a certain shift at a certain occupation and the average risk per identical shift at the same occupation. This does not entirely solve the problem and in fact it raises fresh ones. In road traffic accidents among licence holders, a prolific source of data especially in the United States, computation of exposure to risk is impossible. In public corporation transport companies, duration of driving (or miles driven), routes driven over, times of day of duties, number of days absent from work, etc. are known, and thus more accurate estimates of risk can be calculated; but unfortunately in these organizations certain drivers are perforce associated with certain routes or duties and so the effects of the two variables (drivers and routes) cannot be disentangled. Häkkinen (1958) and Cresswell and Froggatt (1963) tackled this problem from different viewpoints; the former has been commented on by Smeed (1960). Unfortunately, even a modest heterogeneity to accident risk in a group is sufficient to compromise the form of the accident frequency distribution actually obtained. For example, as has already been stated, the Distribution of Unequal Liabilities can arise, using accident data from the whole group, when in fact accidents are randomly distributed, i.e. conform to the Poisson distribution, among each sub-group of true equal-risk. The serious interpretative errors are obvious.

Errors in Ascertainment.-Reporting a trivial accident is largely a subjective decision. Most minor industrial accidents are ascertained through attendances at medical or first-aid departments, e.g. those data used by Greenwood and Woods (1919), Newbold (1926, 1927), Farmer and Chambers (1926), and Smiley (1955). Clearly, individuals will differ in their tendency to report such an event, and so the tendency to report and the tendency to have accidents will be confounded. This fact has been recognized since the pioneer investigations: 'But the nervous or ultra-careful woman [Greenwood was investigating only groups of women] may, for various reasons, 
report accidents which the average woman would disregard altogether' (Greenwood and Woods, 1919). In addition, many accountable factors which are not, for this purpose, easily expressible in statistical terms, e.g. attractiveness or otherwise of a nurse, attitude of workmates, distance of workplace from first-aid department, and temperamental attitudes, will influence an individual's decision. To obviate these difficulties some investigators have considered serious accidents exclusively or accidents which cause the absence of an individual from work for a certain time (e.g. Adelstein, 1952), but this gives an ascertainment almost certainly unrepresentative of a total ascertainment for factors other than severity or duration of relevant absence. For broadly similar reasons, police records and accident claims by private licence holders on insurance companies, two fertile sources of road accident data, may yield inaccurate indices of accident experience, a point put by Johnson and Garwood (1957) when describing their own work: 'It is the liability of policies to claims rather than drivers to accidents that has been studied'. As is the case with exposure to risk, road accidents among public transport drivers provide by far the best source of data. Here, accident ascertainment is nearly complete since the vehicles are examined frequently, each accident can be apportioned to the appropriate driver, and it is difficult to envisage many accidents to a bus, trolley-bus or tramcar which would mark neither vehicle nor victim. But there are snags; among public transport drivers pre-employment selection is considerable, selection of the worst drivers (as measured by the accident record) out of the job is usually heavy, and the total number of accidents incurred by the group is small.

In short there are no perfect data extant for a reliable study of accident distribution. This fact must be borne in mind when assessing the results of published work.

\section{The Concept of Accident Proneness}

The ability of the Distribution of Unequal Liabilities to fit frequency distributions of accidents among groups of munition workers, and the values of certain correlation coefficients calculated between the numbers of accidents incurred by individuals in two different periods of time, prompted Greenwood and Woods (1919), with stated reservations, to write: 'These results indicate that varying individual susceptibility to "accident" is an extremely important factor in determining the [accident frequency] distribution'. Thus the hypothesis of $a b$ initio unequal liability became from the very outset the paramount concept '... not because Mr. Yule and I proved [it] but for non-mathematical reasons' (Greenwood, 1941). The 'non-mathematical reasons' were its seeming coherence in the scientific climate of the early nineteen-twenties, and the eminently practical one that ultimately it might prove possible to detect 'susceptible' persons before they had incurred any accidents at all, with the obvious application to vocational guidance. Accordingly, the Industrial Fatigue Research Board initiated further research along three lines, namely statistical (Newbold, 1926), clinical (Farmer and Chambers, 1926), and laboratory (e.g. Crowden, 1928).

Newbold (1926), with qualifications, concluded: 'The average number of accidents is much influenced by a comparatively small number of workers . . . From this, and from Greenwood and Woods' (1919) earlier study, Farmer and Chambers (1926) extravagantly claimed that 'previous statistical investigations have shown that industrial workers exposed to equal risks were unequal in their liability to sustain accidents, and that this unequal liability was a relatively stable phenomenon'. On the basis of their own research on groups of industrial workers, they concluded: 'A relationship has been shown to exist in the subjects examined between accidents on the one hand and poor "aestheto-kinetic co-ordination" and nervous instability on the other'. They thus introduced the term 'accident prone'* to describe persons whose unsatisfactory accident record was due to 'personal' factors: “'Accident proneness" is a narrower term than "accident liability", and means a personal idiosyncrasy predisposing the individual who possesses it in a marked degree to a relatively high accident rate. "Accident liability" includes all the factors determining accident rate: "accident proneness" refers only to those that are personal' (Farmer and Chambers, 1926). But although they subsequently modified certain of their ideas (e.g. Farmer, Chambers, and Kirk, 1933; Farmer, 1938; Farmer and Chambers, 1939), broadly speaking they conceived accident proneness to be immutable such that individuals were fixed in their inherent liability to incur an accident. Passages can be found in their later writings apparently to refute this statement (e.g. Chambers and Yule, 1941), but this remained their general thesis.

From these beginnings the concept of accident proneness as an innate and stable characteristic was avidly accepted by most doctors and psychologists, and subsequent research aimed at finding some characteristic or characteristics in the wide range from corporal dexterity to the psyche that would correlate with and predict accident experience. At

*The word 'prone' in connexion with accidents was apparently first used in the preface to the I.F.R.B. Report of Osborne, Vernon, and Muscio (1922). 
first minor industrial accidents were used, and the search was for lack of manual skills and dexterity (e.g. Langdon, 1932), as suggested by Farmer and Chambers' (1926) original study, but during the nineteen-thirties road accidents (e.g. Lauer and Kotvis, 1934; DeSilva, 1939, 1942; Johnson and Cobb, 1938; Johnson, 1939; Farmer and Chambers, 1939), and during the nineteen-forties aircraft and service driving accidents (see Thorndike (1951) and McFarland, Moore, and Warren (1955) for extensive reviews), predominated, and the characteristics sought became increasingly those of 'temperament', higher cognitive and conative function, and other aspects of the persona 'measurable' by paper-andpencil tests. Due perhaps to the new emphasis on personnel selection during the Second World War, this enthusiasm was not always matched by strict methodology, and during the nineteen-forties the nadir was reached when Flanders Dunbar (1943) could write: 'These studies [on the temperament of some hospital fracture patients] suggest that the accident prone person can be spotted rather easily. Actually he can be spotted with less expense than the person with tuberculosis or heart disease, for whom the expense of roentgenograms is often required [sic]'. In fact so undisciplined had much of the research become that Greenwood (1950), in the last article he ever wrote and which was published posthumously, Mintz and Blum (1949), Arbous and Kerrich (1951), and Adelstein (1952) clearly felt impelled to re-state some of the desiderata of a proper study.

These papers mark a watershed in two ways, which are in a sense complementary. First, most subsequent studies were conducted with more attention to statistical method and valid data; and secondly, since the search for characteristics of the accident prone had been in the main unsuccessful and the concept largely discordant with contemporary theories of human activity, there was a growing heresy that perhaps the very concept itself should be re-appraised. The first point has been discussed above; the second is now considered.

\section{Implications of Accident Proneness}

If accident proneness were a stable entity, as classically conceived, then not only should a frequency distribution of accidents be graduated by the Distribution of Unequal Liabilities but the same individuals should be present in the 'tail' of the distribution in every observational period of reasonable duration. This latter is best measured by examining the behaviour of the correlation coefficients between the numbers of accidents incurred by individuals in two periods of exposure. These coefficients should be as follows if the concept is tenable: (1) Significant and reasonably stable; (2) independent of the length of the interval between the time periods the accidents within which are being correlated; (3) not tend to become non-significant even if these periods are separated by a very long interval, provided other factors likely to influence the frequency distribution of the accidents are held constant.

Only the studies of Farmer and Chambers (1929) and Farmer, Chambers, and Kirk (1933) with industrial data, and Farmer and Chambers (1939), Häkkinen (1958), and Cresswell and Froggatt (1963) with accidents from public corporation road transport drivers present sufficient information to judge the behaviour of the correlation coefficients.

The results are summarized in Tables 4 to 9. Many of the coefficients were considered to be

TABLE 4

CORRELATION COEFFICIENTS BETWEEN THE NUMBERS OF ACCIDENTS INCURRED IN DIFFERENT YEARS (COMPILED FROM FARMER AND CHAMBERS, 1929)

\begin{tabular}{|c|c|c|}
\hline Years & 1 & 2 \\
\hline $\begin{array}{l}\text { Group III } \\
\text { (524 R.A.F. Apprentices) } \\
3 \\
3\end{array}$ & $\begin{array}{l}0.382 \\
0.338\end{array}$ & 0.443 \\
\hline $\begin{array}{c}\text { Group IV } \\
\text { (259 R.A.F. Apprentices) } \\
3_{3}\end{array}$ & $\begin{array}{l}0.390 \\
0.223\end{array}$ & 0.360 \\
\hline $\begin{array}{c}\text { Group VII } \\
\text { (100 Royal Dockyard } \\
\text { Apprentices) } \\
\mathbf{2} \\
\mathbf{3}\end{array}$ & $\begin{array}{l}0.327 \\
0.327\end{array}$ & 0.246 \\
\hline
\end{tabular}

TABLE 5

CORRELATION COEFFICIENTS BETWEEN THE NUMBERS OF ACCIDENTS INCURRED IN DIFFERENT YEARS (ABRIDGED FROM FARMER, CHAMBERS, AND KIRK, 1933)

\begin{tabular}{c|c|c|c|c}
\hline Years & 1 & 2 & 3 & 4 \\
\cline { 1 - 3 } $\begin{array}{c}\text { Shipwrights (101 Boy } \\
\text { Apprentices) }\end{array}$ & & & & \\
2 & 0.440 & & & \\
3 & 0.357 & 0.187 & & \\
4 & 0.278 & 0.178 & 0.195 & \\
5 & 0.245 & 0.199 & 0.136 & 0.104 \\
\hline
\end{tabular}

TABLE 6

CORRELATION COEFFICIENTS BETWEEN THE NUMBERS OF ACCIDENTS INCURRED IN DIFFERENT YEARS (COMPILED FROM FARMER AND CHAMBERS, 1939)

\begin{tabular}{c|c|c|c|c}
\hline Years & 1 & 2 & 3 & 4 \\
\hline Group A (166 & & & & \\
London Bus Drivers) & 0.298 & & & \\
2 & 0.235 & 0.328 & & \\
3 & 0.177 & 0.176 & 0.212 & \\
4 & 0.274 & 0.265 & 0.273 & 0.224 \\
\hline
\end{tabular}


TABLE 7

CORRELATION COEFFICIENTS BETWEEN THE NUMBERS OF ACCIDENTS INCURRED IN DIFFERENT YEARS (HÄKKINEN, 1958)

\begin{tabular}{cc|c}
\hline \multicolumn{2}{c|}{ Years } & Correlation Coefficient \\
\hline $\begin{array}{c}\text { Group A (101 Helsinki Bus } \\
\text { Drivers) }\end{array}$ & \\
& $6 / 5$ & 0.370 \\
$6 / 4$ & $0 \cdot 191$ \\
$6 / 3$ & 0.250 \\
$6 / 2$ & 0.242 \\
$6 / 1$ & 0.034 \\
\hline
\end{tabular}

TABLE 8

CORRELATION COEFFICIENTS BETWEEN THE NUMBERS OF ACCIDENTS INCURRED IN DIFFERENT YEARS (CRESSWELL AND FROGGATT, 1963)

\begin{tabular}{c|c|c}
\hline Years & $1952-53$ & $1954-55$ \\
\cline { 1 - 2 } $\begin{array}{c}\text { Ulster Transport Authority } \\
\text { Bus Drivers (380 Men) } \\
1954-55\end{array}$ & & \\
$1956-57$ & 0.239 & \\
\hline
\end{tabular}

TABLE 9

CORRELATION COEFFICIENTS BETWEEN THE NUMBERS OF ACCIDENTS INCURRED IN DIFFERENT YEARS (CRESSWELL AND FROGGATT, 1963)

\begin{tabular}{c|c|c|c|c}
\hline Years & 1951 & 1952 & 1953 & 1954 \\
\hline $\begin{array}{c}\text { Ulster Transport } \\
\text { A uthority Bus }\end{array}$ & & & & \\
Drivers (708 Men) & & & & \\
1952 & 0.097 & & & \\
1953 & 0.111 & 0.266 & & \\
1954 & 0.148 & 0.136 & 0.259 & \\
1955 & 0.052 & 0.216 & 0.118 & 0.185 \\
\hline
\end{tabular}

significant in that they were several times their standard error, ${ }^{*}$ but as far as can be gathered they are far from stable, and in addition the suspicion is that the values of the coefficients in fact decrease as the respective time-periods become more remote. (The importance of this is discussed by Cresswell and Froggatt (1963).) Indeed all the cited authors, except Cresswell and Froggatt, give the last finding as a definite conclusion. The evidence of correlation does not therefore support the thesis of accident proneness, but it must be interpreted with caution since unequal exposure to risk, which must have operated in at least some of these groups, may in itself compromise the values of the correlation coefficients, and the skewness of the distribution of the variates makes drawing conclusions based on 'differences' between the coefficients hazardous.

On a more pragmatic basis, if accident proneness were a stable entity, then if those individuals with the worst accident record in any one period were subsequently excluded, there should be a resultant decrease in the frequency of accidents incurred by

\footnotetext{
* Since neither variate was normally distributed the assumption of
} significance is to some extent speculation. the remainder over all subsequent observational periods. Table 10, the second row of figures in Table 11, and the first row in Table 12 show, in the admittedly unrealistic situation where the experiences of selected groups were simply removed from the calculations, that such improvement was not always effected without also excluding many individuals whose subsequent accident experience was unremarkable. (On the same basis, Tables 9 and 10 also show the disappointing prediction ability of the aestheto-kinetic tests.) Also, if individual liability has a Pearson type III distribution, as Greenwood theorized, then when the time intervals between successive accidents are analysed the Distribution of Unequal Liabilities should provide an adequate basis for estimating the numbers of 'accident repeaters' actually observed. This has not proved to be the case (Cresswell and Froggatt, 1963).

TABLE 10

EFFECT OF REMOVING THE MEN WITH THE HIGHEST ACCIDENT RATE IN THE FIRST YEAR (ABRIDGED FROM ADELSTEIN, 1952)

\begin{tabular}{|c|c|c|c|}
\hline $\begin{array}{l}\text { Average Accident Rate for } \\
\text { Shunters joining in } 1944\end{array}$ & $\begin{array}{l}\text { First } \\
\text { Year }\end{array}$ & $\begin{array}{l}\text { Second } \\
\text { Year }\end{array}$ & $\begin{array}{l}\text { Third } \\
\text { Year }\end{array}$ \\
\hline \multirow{2}{*}{$\begin{array}{l}\text { (a) For all } 104 \text { men } \\
\text { (b) If worst } 10 \text { for the first year } \\
\text { were removed-94 men }\end{array}$} & 0.557 & 0.355 & 0.317 \\
\hline & 0.393 & 0.361 & 0.329 \\
\hline
\end{tabular}

TABLE 11

EFFECT ON SUBSEQUENT ACCIDENT RATE OF REMOVING DRIVERS WITH (1) MANY ACCIDENTS IN THEIR FIRST YEAR, OR (2) POOR AESTHETO-KINETIC CO-ORDINATION (ABRIDGED FROM FARMER AND CHAMBERS, 1939)

\begin{tabular}{l|c|c|c}
\hline Action & $\begin{array}{c}\text { Drivers } \\
\text { Removed } \\
(\%)\end{array}$ & $\begin{array}{c}\text { Accident } \\
\text { Rate } \\
(\%)\end{array}$ & $\begin{array}{c}\text { Reduction } \\
\text { Effected } \\
(\%)\end{array}$ \\
\hline $\begin{array}{c}\text { Accident rate for whole group for } \\
\text { all years except the first }\end{array}$ & & 100 & 9 \\
(1) After removing drivers with \\
$\begin{array}{c}\text { three or more accidents in } \\
\text { the first year }\end{array}$ & 28 & 91 & 9 \\
(2) After removing the worst & 23 & 93 & 7 \\
(3) Combining (1) and (2) & 44 & 87 & 13 \\
\hline
\end{tabular}

TABLE 12

MEAN PERCENTAGE ACCIDENT RATE OVER THE WHOLE PERIOD (FIVE YEARS) OF GROUPS SELECTED BY DIFFERENT MET HODS, TAKING THE ACCIDENT RATE OF THE WHOLE OBSERVED GROUP AS $100 \%$
(FARMER, CHAMBERS, AND KIRK, 1933)

\begin{tabular}{c|c|c|c}
\hline Accident Rate & $\begin{array}{c}\text { Ship- } \\
\text { wrights }\end{array}$ & $\begin{array}{c}\text { Electric } \\
\text { Fitters }\end{array}$ & $\begin{array}{c}\text { Engine } \\
\text { Fitters }\end{array}$ \\
\begin{tabular}{c|c|c} 
1. Of those left after rejecting \\
the high accident subjects \\
in the first year
\end{tabular} & 87 & 99 & 94 \\
$\begin{array}{c}\text { 2. Of top three inter-quartile } \\
\text { groups of the aestheto- }\end{array}$ & 80 & 88 & 90 \\
$\begin{array}{c}\text { kinetic tests } \\
\text { 3. Combination of methods 1 } \\
\text { and 2 }\end{array}$ & 75 & 88 & 79 \\
$\begin{array}{c}\text { 4. Of top inter-quartile group } \\
\text { only in the aestheto-kinetic } \\
\text { tests }\end{array}$ & 61 & 60 & 74 \\
\hline
\end{tabular}




\section{Characteristics of the Accident Prone}

The corollary of accepting accident proneness as a stable characteristic is to find means to 'measure' it. This has justified the protracted search for some characteristic, biological or otherwise, which would correlate with and predict accident experience, or for a test or battery of tests which would allow one to identify the accident prone with some certainty. Tests of corporal, sensori-motor, and aesthetokinetic skills were early used for motorman and transport driver selection by Münsterberg (1913), Stern (1918), Lahy (1927), and Slocombe and Brakeman (1930), as well as for research among industrial workers (Farmer and Chambers, 1926; Farmer, Chambers, and Kirk, 1933). Their popularity reached a peak in the early nineteen-thirties, at which time they were incorporated for personnel selection in many countries including Britain (Miles and Vincent, 1934). From then scepticism as to their efficacy mounted, and when Flanders Dunbar's (Dunbar, Wolfe, and Rioch, 1936; Dunbar, Wolfe, Tauber, and Brush, 1939) findings on hospital groups of fracture patients led her to re-introduce Freud's 'traumatophilic diathesis' as a characteristic of the accident prone, the search shifted to the realm of personality in its widest connotation. At first, among drivers interests and attitudes were the qualities measured (Cobb, 1939; Brody, 1941), but those facets of temperament measurable by paper-andpencil tests were soon added (e.g. ENO Foundation, 1948; Ghiselli and Brown, 1949; Tillmann and Hobbs, 1949; Bartelme, Fletcher, Brown, and Ghiselli, 1951; Parker, 1953; Suhr, 1953; Lauer, 1955; McGuire, 1956, a, b, c, d; Häkkinen, 1958). Some of these authors obtained correlations between certain of the tests and the accident record, or differences in test scores between 'high' and 'low' accident groups, and some did not; and although the realm of personality remained transcendent, in general the results achieved were inconclusive.

This led to a re-appraisal of the concept. Broadly speaking, three modifications were suggested.

1. That accident proneness, as measured by the accident record, changes with time. This had a strong appeal, especially to Greenwood (1941) and Chambers (Chambers and Yule, 1941), for the following reason. It was generally accepted that in industry (Chaney and Hanna, 1918; Gates, 1920; Fisher, 1932; Humke, 1936) and on the road (Slocombe and Bingham, 1927; Farmer and Chambers, 1939) the least experienced individuals had ceteris paribus the greatest number of accidents. Also, age appeared to have an independent effect on the accident rate (see King and Speakman (1953) and
Froggatt (1962) for reviews). Consequently, on this evidence stable accident proneness would appear absurd. But an accident is an overt consequence, and statistically proneness is inferred ex post facto; therefore the accident rate could vary without necessarily implying any change in the underlying diathesis, e.g. in accident proneness. In fact it has been established that the accident records can provide a very inaccurate guide to the individuals' accident proneness (Cresswell and Froggatt, 1963). These authors related the theorized proneness component to the accident records of bus drivers, and, as was to be expected, the greater the number of accidents incurred (r) the greater the proneness component (Table 13). But the $90 \%$ confidence limits of the

TABLE 13

90\% CONFIDENCE LIMITS FOR 'ACCIDENT LIABILITY' GIVEN THAT A DRIVER SUFFERS r ACCIDENTS DURING THE PERIOD 1952-55

(ABRIDGED FROM CRESSWELL AND FROGGATT, 1963)

\begin{tabular}{|c|c|c|}
\hline \multirow{2}{*}{$\mathbf{r}$} & \multicolumn{2}{|c|}{ Accident Liability } \\
\hline & $\begin{array}{l}\text { Belfast Corporation } \\
\text { Bus Drivers }\end{array}$ & $\begin{array}{l}\text { Belfast Corporation } \\
\text { Trolley-bus Drivers }\end{array}$ \\
\hline $\begin{array}{r}0 \\
1 \\
2 \\
3 \\
4 \\
5 \\
6 \\
7 \\
8 \\
9 \\
10\end{array}$ & $\begin{array}{l}0.482-2 \cdot 075 \\
0.621-2 \cdot 358 \\
0.766-2 \cdot 636 \\
0.914-2.909 \\
1 \cdot 067-3 \cdot 178 \\
1 \cdot 222-3.445 \\
1 \cdot 380-3 \cdot 709 \\
1 \cdot 541-3.970 \\
1 \cdot 703-4 \cdot 230 \\
1 \cdot 867-4.487\end{array}$ & $\begin{array}{l}0.417-2 \cdot 123 \\
0.574-2 \cdot 469 \\
0.739-2 \cdot 806 \\
0.911-3.136 \\
1.088-3.461 \\
1 \cdot 269-3 \cdot 782 \\
1.454-4.099 \\
1.643-4 \cdot 413 \\
1 \cdot 833-4 \cdot 724 \\
2.026-5.033 \\
2 \cdot 222-5 \cdot 340\end{array}$ \\
\hline
\end{tabular}

estimates showed considerable overlapping through the range of $r$. Consequently, from the table it would be imprudent to assert that, for example, in the circumstances of that particular study a driver incurring nine accidents over the period was certainly more 'prone' to accident than a driver incurring only one. If this finding were general, as might be presumed, this modified hypothesis would be tenable and almost impossible to discredit.

2. That the permanently accident prone comprise only a very small proportion of those persons with an unsatisfactory accident record in any one observational period. This is a forced retreat from the more extravagant ideas of the nineteen-twenties and -thirties, but it was one made by many of the most experienced investigators, although so imperceptibly that Adelstein (1952), in his classic study, could be excused when he failed fully to appreciate it and so drew Chambers' (1952) criticism. The adequacy of this modification to explain the facts depends largely upon the selection processes operating on the group from which data were obtained. 
3. That accident proneness is not a stable entity but varies for each person from time to time. This hypothesis has attracted more attention than (1) and (2) and is now considered in detail.

\section{The Concept of Variation in Accident Proneness}

As already stated, the concept of accident proneness arose from Greenwood's 'third' hypothesis of accident genesis, the statistical basis of which was founded on considerations of practical convenience and not on any inherent belief in the rationale of the specific hypothesis involved. But a price was paid for such technical facility; the hypothesis of stable proneness is so mechanistic in concept that its validity in the human situation seems hardly credible. Whatever justification it may possess in unselected industrial groups, and this is slight, it possesses none at all for highly selected road transport drivers. Here bad performers are barred or weeded out, and in addition there are other drivers, cyclists, and pedestrians on the road so that allowance for the influence of a third party must always be made: 'Any statistics of accidents must contain a number of events which have no connection with the personal qualities of the exposed to risk' (Greenwood, 1950). During and after the Second World War clinicians increasingly came to suspect that human performance-and therefore liability (or 'tendency') to accident-varied from time to time within persons as well as between persons (e.g. Ghiselli and Brown, 1948; Arbous and Kerrich, 1951) and that such variation was neither independent of the severity of environmental 'strain' nor of the temperament of the individual, two factors which could interact. This was strictly discordant with popular theory, where accident proneness was assumed immutable, but it was a more realistic and 'human' concept.

At once Davis (1948 a, b; 1949) and others, and later Venables $(1955,1956)$, tried to establish that consistency of performance (as measured) either on simulated tasks or in the real-life situation was reciprocally related to neuroticism. Then, the argument could go, since consistency of performance (as measured) is related to driving skill (Lewis, 1956), neuroticism and driving skill must be negatively correlated. Since neurotic activity fluctuates, driving skill (and therefore accident liability) would also fluctuate. In this, for various reasons, they were only partly successful. About the same time one of us (Smiley, 1955) extended this concept to the general industrial field by examining two groups of men selected on the number of accidents reported to factory medical and first-aid departments. The first group examined comprised those with an excessive number of accidents over a two-year period; the second group was an approximately equal-sized random sample of men from the same factory. Smiley found unequivocal evidence that his first group was more 'neurotic' (as measured by Culpin's (Culpin and Smith, 1930) groupings) than his second, and from this and other findings he described the accident prone as neurotic individuals with exaggerated emotional response due 'either to stimulation of the hypothalamus by impulses from the cortex, or to a diminution of the inhibitory impulses from that area' (Smiley, 1955). These impulses then produced minor imbalances of adrenaline or acetylcholine, which in turn resulted in muscular disharmony with reduced performance, especially skilled or fine performance.

Smiley also described several case histories of persons who were excessively distraught, who scored highly (badly) on Culpin's assessment, and who during the survey had an excessive number of accidents. The same persons, when their temporary anxieties had been relieved, scored lower on Culpin's assessment, and the number of accidents they incurred fell sharply. In fact, although persons may differ in their initial liability to accident due to 'personal' factors, as hypothesized by the pioneer workers, their liability to accident could vary through time due to the interaction of 'personal' and 'environmental' causes. This could explain the comparative failure of the attempts to isolate the accident prone by psychological tests in that when examined after the period of exposure to the risk of accident the spell may have 'worn off'. What was now required was to establish a statistical basis for the coherence of this thesis. This could only be attempted by using accidents among public transport drivers because of the requirements of valid data. Such a study has the disadvantages that $(a)$ the statistical theory would have to allow for the fact that for many recorded accidents the transport driver was not solely culpable, $(b)$ the accidents would be infrequent and would be statistical 'rare events', and $(c)$ the group would be a highly selected one.

Using road accidents among public transport drivers in Northern Ireland over a four-year period, Cresswell and Froggatt (1963) formulated an hypothesis basically similar to Smiley's but with modifications necessary on account of the different class of data. The hypothesis was that every driver is liable to 'spells' during which his liability to incur an accident is increased. These spells are rare events and occur by chance. Also, all drivers are reckoned equally likely to incur a spell, and all men incurring a spell are equally likely to have an accident during their respective spells. Furthermore, some accidents are allowed to occur at random independent of 'spell' accidents. They tested the respective abilities 
of this hypothesis and that of stable accident proneness to explain certain aspects of their data. From the evidence, they theorized that among their groups of transport drivers an hypothesis which allows both personal fluctuation in accident liability and accidents for which the driver is not solely culpable is more realistic and in closer accord with the statistics than is the hypothesis of immutable liability. They did not claim it to be a complete explanation of the facts; no one hypothesis could be that; but they concluded that permanent accident proneness was in general even less appropriate, although it may operate among a few drivers. Clearly, in a 'closed community', such as in most industrial situations, the hypothesis is not fully suitable since it allows for accidents due to a third party, and therefore a modification of the theory would be necessary. (Such a modification was in fact put forward by Cresswell and Froggatt.) Also, among drivers less heavily selected than professional drivers, unskilled performers may continue to drive irrespective of their accident experience, and so the proportion who are accident prone may be greater. It would, however, appear difficult to collect sufficiently valid data on such groups to make their analysis worth while.

Whether or not there exist individuals who, in a given situation, are more likely at all times to incur an accident than their fellows exposed to similar risk, the more recent work clearly suggests that temporary fluctuations induced either by environmental or endogenous factors should be taken into account when considering accident causation. Such fluctuations are in the nature of things. Thus research into the role of 'temporary attributes of the individual', as they are termed by Thorndike (1951), such as worry, distraction, and ill-health, and their effect on factors such as vigilance and fatigue, becomes meaningful. Unfortunately, to devise appropriate field studies seems almost impossible in practice. The many facets of an individual's make-up, environment, and activities, which should be examined, would make for a team project of formidable scope. It would have to be a prospective study, with all that that entails, and would require inter alia the continuing co-operation of the members of the experimental group and their families. Furthermore, to ensure valid data, an experimental design along, say, the lines of a Latin Square would be desirable but would require a degree of control over the subjects hardly obtainable in practice.

During the First World War investigators realized the temporary nature of much increased 'susceptibility' to accident. This was a milieu in which 'spells' could be easily envisaged since probably many of the women munition workers, who comprised the populations studied, had relatives in France, apart altogether from the increased pressure of long hours of work and life on the home front. In a sense the wheel has turned full circle, although much useful information has been learned in its revolution. Had the scientific climate been less sanguine for its application; or had some of the field workers understood the statistical theory as well as did Eric Farmer and E. G. Chambers or been less extravagant in their claims; or again had the statisticians written more and in less specialist journals (apart from questions at meetings, Greenwood published nothing on accident proneness between his paper with Yule in the Journal of the Royal Statistical Society in 1920 - which formed the basis for the theory-and his article in Biometrika 30 years later), then perhaps accident proneness would never have been so completely accepted as established fact.

\section{The Practical Outcome of Accident Proneness}

The theoretical basis for accident proneness could be dismissed as academic if the acceptance of the concept had contributed to the reduction in accident rates, both in industry and on the roads, to anything like the same extent as did the improvement in the milieu extérieur in its widest connotation. Accidents certainly have been decreasing in number. In Britain the number of reported* accidents in factories per 1,000 'workers' employed declined steadily (with the exception of the war years) from 1937, when the present system of recording was introduced, until the late nineteen-fifties, since when it has tended to rise (Chief Inspector of Factories, 1955, 1962). The improvement was due principally to a decrease in accidents to men; for women the rates have shown little change since 1947. On the road the numbers of accidents per licensed vehicle and per million miles driven have also fallen over the period (Norman, 1960). Too much, however, should not be read into these figures since they do not allow for any differences in age, job, or driving experience structures between the compared populations, variables which have proven effects on the accident rate.

But the respective contributions of the personal and environmental factors to this reduction are difficult to estimate from available data. In industry, the British Industrial Safety First Association was formed in 1918, and in the nineteen-twenties and -thirties numerous safety committees were established. Further improvement in protective devices for machinery were effected subsequent to the Factories Act 1937. On the road the London Safety First Council was formed in 1917, and in 1924 it

\footnotetext{
*As defined under Section 64 of the Factories Act 1937.
} 
amalgamated with other such bodies to form the National 'Safety First' Association. The Road Traffic Act 1930 introduced inter alia compulsory third-party insurance, minimum age limits for drivers, and the penalty of disqualification, and that of 193430 miles per hour speed limits in built-up areas, pedestrian crossings with Belisha beacons, and driving tests. Thus organizations which were largely devoted to reducing the environmental risk, and statutory backing for many of their recommendations, were introduced about the same time as was the concept of accident proneness. It is impossible to decide what part of the subsequent improvement in accident record could be attributed to each of these factors. All that can be said is that results of tests of accident prediction have been disappointing. Tables 10 to 12 show what would have been the result ceteris paribus if those methods most commonly used in accident prediction had been applied to certain experimental groups; there would not have been any marked reduction in the overall accident rate at all. In fact it can be argued that acceptance of the concept of accident proneness has been actually harmful since many employers may have been dissuaded from accepting their full responsibilities: 'If a supervisor believes that a worker is accident prone he is likely to assume that the case is out of his hands' (DeReamer, 1958). Newbold (1926) many years ago put the problem in perspective: 'In dealing with the human factor we do not intend in the least to minimize the importance of the mechanical side of accident cause and prevention, or to show any sympathy with the neglect of the first and most clearly necessary duty of any employer to make all machinery and working conditions as free from risk and as foolproof as possible'.

Finally, should the term accident proneness be dropped? Some investigators have suggested using the term 'temporary accident proneness' for periods of increased liability, but this is a contradiction in terms. Norman (1962) suggests using 'accident repeater' to describe a person 'who has more than a given number' of accidents in a given time, the 'repeater condition' being either temporary or permanent. This is an improvement since it excludes the word 'prone', which has such an inflexible connotation, and it is suitably non-committal as regards causation. The pioneer investigators used such terms as 'individual susceptibility to accident' (Greenwood and Woods, 1919), 'personal susceptibility', 'individual tendency', and 'personal tendency' (Newbold, 1926) as blanket expressions to cover the array of disparate motives or factors comprising the aetiological component in propria persona. 'Accident liability' has unfortunately been used indiscriminately by some, although more specifically by others: 'We regard accident proneness as an individual quality of relative permanence, and use accident liability as the sum total of all the factors determining accident causation' (Farmer, 1938). Cresswell and Froggatt (1963) suggest 'variable accident tendency' to accord with their thesis of accident causation. Certainly, variation in human abilities due to personal and environmental causes is in the nature of things, and tendency to accident is an undoubted hazard of living. But the wisest course might be to discourage the use of any catch phrase; the abuse of 'accident proneness' must always serve as a grim example.

\section{BIBLIOGRAPHY}

Adelstein, A. M. (1952). Accident proneness: A criticism of the concept based upon an analysis of shunters' accidents. J.R. statist. Soc. A, 115, 354.

Agricola, G. (1556). De Re Metallica. Translated from the first Latin Edition of 1556 by H. C. and L. H. Hoover. The Mining Magazine, 1912, London.

Arbous, A. G., and Kerrich, J. E. (1951). Accident statistics and the concept of accident proneness. Biometrics, 7,340 .

Bartelme, P. F., Fletcher, E. D., Brown, C. W., and Ghiselli, E. E. (1951). The prediction of driving skill. J. appl. Psychol., 35, 98.

Brody, L. (1941). Personal Factors in Safe Operation of Motor Vehicles, p. 96. Center for Safety Education, New York University.

Chambers, E. G. (1952). Discussion on Dr. Adelstein's paper. J.R. statist. Soc. $A, 115,408$.

- , and Yule, G. U. (1941). Theory and observation in the investigation of accident causation. Ibid., Suppl. 7, 89.

Chaney, L. W., and Hanna, H. S. (1918). The Safety Movement in the Iron and Steel Industry, 1907-1917. Bull. U.S. Bureau of Labor Statistics, No. 234.

Chief Inspector of Factories (1955). Annual Report of the Chief Inspector of Factories for 1954. H.M. Stationery Office, London.

(1960). Annual Report of the Chief Inspector of Factories for 1959. H.M. Stationery Office, London.

(1962). Annual Report of the Chief Inspector of Factories for 1961. H.M. Stationery Office, London.

Chief Inspector of Mines (1957). Report of H.M. Chief Inspector of Mines for the Years 1954-1956. H.M. Stationery Office, London.

Cobb, P. W. (1939). Automobile Driver Tests administered to 3,663 Persons in Connecticut, 1936-1937, and the Relation of the Test Scores to the Accidents sustained. Report to the Highway Research Board, Washington, D.C. Unpublished.

Cresswell, W. L., and Froggatt, P. (1963). The Causation of Bus Driver Accidents. An Epidemiological Study. Oxford University Press, London.

Crowden, G. P. (1928). The Physiological Cost of the Muscular Movements involved in Barrow Work. Rep. Industr. Fat. Res. Bd., Lond., No. 50.

Culpin, M., and Smith, M. (1930). The Nervous Temperament. Rep. Industr. Hith Res. Bd., Lond., No. 61.

Davis, D. R. (1948a). Pilot Error: Some Laboratory Experiments. Air Ministry A.P. 3139 A. H.M. Stationery Office, London.

(1948b). Increase in strength of a secondary drive as a cause of disorganisation. Quart. J. exp. Psychol., 1, 22.

(1949). The disorder of skill responsible for accidents. Quart. J. exp. Psychol., 1, 136.

DeReamer, R. (1958). Modern Safety Practices. Wiley, New York. DeSilva, H. R. (1939). Normal versus accident drivers. J. Psychol., 7, 337 .

(1942). Why we have Automobile Accidents. Wiley, New York. Dunbar, H. F. (1943). Psychosomatic Diagnosis. Hoeber, New York.

-, Wolfe, T. P., and Rioch, J. McK. (1936). Psychiatric aspects of medical problems. The psychic component of the disease process in cardiac, diabetic and fracture patients (Part 1), Amer. J. Psychiat., 93, 649.

—, Wolfe, T. P., Tauber, E. S., and Brush, A. L. (1939). Psychiatric aspects of medical problems. The psychic component of the aspects of medical problems. The psychic component of the
disease process in cardiac, diabetic and fracture patients (Part 2). Amer. J. Psychiat., 95, 1319.

ENO Foundation (1948). Personal Characteristics of Traffic-Accident Repeaters. ENO Foundation for Highway Traffic Control, Sagatuck, Conn., U.S.A. 
Farmer, E. (1938). Critical notice. Brit. J. Psychol., 28, 350.

- and Chambers, E. G. (1926). A Psychological Study of Individual Differences in Accident Rates. Rep. Industr. Fat. Res. Bd. Lond. No. 38.

(1929). A Study of Personal Qualities in Accident Proneness and Proficiency. Rep. Industr. Hlth Res. Bd., Lond., No. 55.

Drivers. Rep. Industr. Hith Res. Bd., Lond., No. 84. Industr. Hith Res. Bd. Lond. No. 68 .

Farr, W. (1865). Twenty-Eighth Annual Report of the RegistrarGeneral of Births, Deaths, and Marriages in England, p. 180. H.M. Stationery Office, London.

- (1875). Thirty-Eighth Annual Report of the Registrar-General of Births, Deaths, and Marriages in England, p. 235 . H.M. Stationery Office, London.

Fisher, H. L. (1932). Quoted in Viteles (1932).

Froggatt, P. (1962). The influence of age upon the accident experience of bus drivers. Ann. occup. Hyg., 5, 53.

Gates, D. S. (1920). A statistical study of accidents in cotton mills, print works, and worsted mills of a textile company. J. industr. Hyg., 2, 286.

Ghiselli, E. E., and Brown, C. W. (1948). Personnel and Industrial Psychology. McGraw-Hill, New York.

- (1949). The prediction of accidents of taxicab drivers. J. appl. Psychol., 33, 540.

Greenwood, M. (1927). Discussion on Miss Newbold's paper. J.R. statist. Soc., $90,536$.

(1941). Discussion on Chambers and Yule's paper. J.R. statist. Soc., Suppl., 7, 107.

- (1949). Discussion on Dr. Smeed's paper. Ibid., A., 112, 25.

(1950). Accident proneness. Biometrika, 37, 24.

_, and Woods, H. M. (1919). The Incidence of Industrial Accidents upon Individuals with Special Reference to Multiple Accidents. upon Individuals with Special Reference to

__, and Yule, G. U. (1920). An inquiry into the nature of frequency distributions representative of multiple happenings, with particular reference to the occurrence of multiple attacks of particular reference to the occurrence of multiple attack
disease or repeated accidents. J.R. statist. Soc., 83, 255.

Häkkinen, S. (1958). Trafhc Accidents and Driver Characteristics. A Statistical and Psychological Study. Helsinki: Finland's Institute of Technology, Scientific Researches, No. 13.

Humke, H. L. (1936). First month found most dangerous. Personnel J., 14, 336.

Irwin, J. O. (1941). Discussion on Chambers and Yule's paper. J.R. statist. Soc., Suppl., 7, 101.

Johnson, H. M. (1939). Evidence for educational value in drivers' 'clinics'. Psychol. Bull., 36, 674.

clinics'. Psychol. Bull., 35, 758.

Johnson, N. L., and Garwood, F. (1957). An analysis of the claim records of a motor insurance company. J. Inst. Act., 83, 277.

Kermack, W. O., and McKendrick, A. G. (1925). Applications of mathematics to medical problems. Proc. Edin. math. Soc. $44,98$.

King, H. F., and Speakman, D. (1953). Age and industrial accident rates. Brit. J. industr. Med., 10, 51

Lahy, J. M. (1927). La Sélection Psychophysiologique des Travailleurs, Conducteurs de Tramways et d'Autobus. Dunod, Paris.

Lancet (1961). What price safety. 2, 469.

Langdon, J. N. (1932). An Experimental Study of Certain Forms of Manual Dexterity. Rep. Industr. Hith Res. Bd., Lond., No. 66.

Lauer, A. R. (1955). Comparison of group paper and pencil tests with certain psychological tests for measuring driving aptitude of army personnel. J. appl. Psychol., 39, 318 .

_ to vision. J. appl. Psychol., 18, 422.

Lewis, R. E. F. (1956). Consistency and car-driving skill. Brit. J. industr. Med., 13, 131.

Lüders, R. (1934). Die Statistik der seltenen Ereignisse. Biometrika, $26,108$.

McFarland, R. A., Moore, R. C., and Warren, A. B. (1955). Human Variables in Motor Vehicle Accidents. A Review of the Literature. Harvard School of Public Health, Boston.

McGuire, F. L. (1956a). The safe-driver inventory. U.S. armed Forces med. J., 7, 1249.

- (1956b). An outline for a new approach to the problem of highway accidents. Ibid., 7, 1157 . (1956c). Psychological comparison of automobile drivers, Ibid.

(1956d). Rosenzweig picture frustration study for selecting safe drivers. Ibid. 7, 200 .

Miles, G. H., and Vincent, D. F. (1934). The Institute's tests for motor drivers. Human Factor, Lond., 8, 245.

Mintz, A., and Blum, M. L. (1949). A re-examination of the accidentproneness concept. J. appl. Psychol. 33, 195

Monthly Digest of Statistics (1960). No. 180. H.M. Stationery Office, London.

Münsterberg, H. (1913). Psychology and Industrial Efficiency, p. 63 seq. Houghton Mifflin, Boston.

Newbold, E. M. (1926). A Contribution to the Study of the Human Factor in the Causation of Accidents. Rep. Industr. Hlth Res. Factor in the Causatio

- (1927). Practical applications of the statistics of repeated events, particularly to industrial accidents. J.R. statist. Soc., 90, 487.

Norman, L. G. (1960). Medical aspects of road safety. Lancet, 1, 989 1039 .

- (1962). Road Traffic Accidents. Epidemiology, Control, and Prevention. Public Health Papers, No. 12. World Health Organization, Geneva.

Osborne, E. E., Vernon, H. M., and Muscio, B. (1922). Two Contributions to the Study of Accident Causation. Rep. Industr. Fat. Res. Bd., Lond., No. 19.

Parker, J. W. (1953). Psychological and personal history data related to accident records of commercial truck drivers. J. appl. Psychol., 37, 317.

Poisson, S. D. (1837). Recherches sur la Probabilité des Jugements, Etc. Bachelier, Paris.

Ramazzini, B. (1705). A Treatise of the Diseases of Tradesmen . . . now done in English. Bell, Smith, etc., London.

Registrar-General (1846). Seventh Annual Report of the RegistrarGeneral of Births, Deaths, and Marriages in England, p. XLIX. H.M. Stationery Office, London.

Roethlisberger, F. J., and Dickson, W. J. (1939). Management and the Worker. An Account of a Research Program conducted by the Western Electric Co., Hawthorne Works, Chicago. Harvard University Press, Cambridge, Mass.

Safety Committees in Factory and Workshops (1918). H.M. Stationery Office, London.

Slocombe, C. S., and Bingham, W. V. (1927). Men who have accidents. Individual differences among motormen and bus operators. Personnel J., 6, 251 .

- , and Brakeman, E. E. (1930). Psychological tests and accident proneness. Brit. J. Psychol., 21, 29.

Smeed, R. J. (1960). Proneness of drivers to road accidents. Nature, Lond. 186,273 .

Smiley, J. A. (1955). A clinical study of a group of accident-prone workers. Brit. J. industr. Med., 12, 263.

Stern, W. (1918). Uber eine psychologische Eignungsprüfung für Strassenbahnfahrerinnen. Z. angew. Psychol., 13, 91.

Suhr, V. W. (1953). The Cattell 16 P.F. test as a prognosticator of accident susceptibility. Proc. Iowa Acad. Sci., 60, 558.

Thackrah, C. T. (1832). The Effects of Arts, Trades, and Professions ... on Health and Longevity, 2nd ed., p. 207. Longman, Rees, etc. London. Republished by E. and S. Livingstone, London. 1957.

Thorndike, R. L. (1951). The Human Factor in Accidents with Special Reference to Aircraft Accidents. U.S.A.F. School of Aviation Med., Rep. No. 1, Project No. 21-30-001. Randolph Field, Texas.

Thyrion, P. (1960). Note sur les distributions 'par grappes'. Bull. Ass. roy. Actuair. Belges, $60,49$.

Tillmann, W. A., and Hobbs, G. E. (1949). The accident-prone automobile driver. Amer. J. Psychiat., 106, 321.

Venables, P. H. (1955). Changes in motor response with increase and decrease in task difficulty in normal industrial and psychiatric patient subjects. Brit. J. Psychol., 46, 101.

patient subjects. Brit. J. Psychol., 46, 101.
(1956). Car-driving consistency and measures of personality. J. appl. Psychol., 40, 21.

J. appl. Psychol., 40, 21 .
Vernon, H. M. (1918). The Factors concerned in the Causation of Industrial Accidents. Health of Munitions Workers Committee, Memo. No. 21. H.M. Stationery Office, London.

Viteles, M. S. (1932). Industrial Psychology. Norton, New York.

von Bortkiewicz, L. (1898). Das Gesetz der kleinen Zahlen. Teubner, Leipzig.

Whitfield, J. W. (1954). Individual differences in accident susceptibility among coal-miners. Brit. J. industr. Med., 11, 126. 